University of Michigan Law School

University of Michigan Law School Scholarship Repository

\title{
Provability in Bankruptcy of Claims Arising out of Alimony Decrees or Separation Agreements between Husband and Wife
}

\author{
Ralph W. Aigler \\ University of Michigan Law School
}

Available at: https://repository.law.umich.edu/articles/1341

Follow this and additional works at: https://repository.law.umich.edu/articles

Part of the Bankruptcy Law Commons, and the Family Law Commons

\section{Recommended Citation}

Aigler, Ralph W. "Provability in Bankruptcy of Claims Arising out of Alimony Decrees or Separation Agreements between Husband and Wife." Mich. L. Rev. 10 (1912): 476-8.

This Response or Comment is brought to you for free and open access by the Faculty Scholarship at University of Michigan Law School Scholarship Repository. It has been accepted for inclusion in Articles by an authorized administrator of University of Michigan Law School Scholarship Repository. For more information, please contact mlaw.repository@umich.edu. 


\section{Michigan LAW REVIEW}

PUBLISEED MONTELY DOXINo TEE ACADEARC YBAR, EXCLUSIVE OP OCTOBER, BY THE

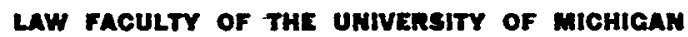

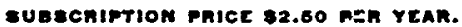

38 CENTE PER NUMER?

JAMIIS H. BREWSTRR, Editor

EvaNS HoLBROOK, Acting Editor

ADVISORY EOARD.

HENRY M. BATES

VICTOR H. IANE

HORACE L. WILGUS

Edtorial Assistants, appointed by the Faculty from the Class of 1912:

Grorge E. BRAND, of Michigan.

IANGDON H. LAXWILI, of Michigan

Phintr H. Cale, of Illinois.

AQUILLA C. LEWIS, of Illinois.

HAROZD R. CURTIS, of Rhode Island. DEAN I. LUCKING, of Michigan.

SIGMUND W. DAVID, of Illinois. LEONARD F. MARTIN, of Illinois.

ALBERI R. DILLEY, of Kansas.

PAUL P. FARRENS, of Iowa.

WALLE W. MERrIT, of Minnesota.

WALTER R. METz, of Nebraska.

NEwTON K. Fox, of District of Columbia.

GRORGE M. FUMPHREY, of Michigan.

VICTOR R. JOSE, JR., of Indiana.

ALBERT E. MEDER, of Michigan.

ELBERT C. MidDleton, of Minnesota.

Stanislaus PIETRAszewski, of New York

ANDREW J. KOLYN, of Michigan. ALBINO Z. SYCIP, of China.

\section{NOTE AND COMMENT.}

Provability in Bankruptcy of Claims Arising out of Alimony Decrees or Separation Agretiments berweEn Husband and Wire.-It was not until the decisions in Audubon v. Shufeldt, 18I U. S. 575, and Wetmore v. Markoe; 196 U. S. 68, that it was authoritatively determined in this country that alimony, whether in arrears at the time of fling petition, or payable in the future, was not provable in bankruptcy. In the first case it was pointed out that an alimony allowance is generally alterable in the discretion of the court entering the original order; but the real basis of the decision appears to havebeen that "permanent alimony is to be regarded rather as a portion of the husband's estate to which the wife is equitably entitled, than as strictly a debt." In the second case it appeared that by the law of New York in which -State the alimony judgment involved had been entered, the allowance was unalterable, and it was urged that the Audubon case, therefore, should not be considered controlling. The court held squarely that alimony, even though evidenced by an unalterable judgment, was not a debt within the Bankruptcy Act. The English courts have taken the same position as to the provability of alimony claims. Linton v. Linton (1885), 15 Q. B. D. 239; Hawkins v. 
Hawkins [1894], I Q. B. 25; Watkins v. Watkins [1896], Prob. 222; Kerr v. Kerr [1897], 2 Q. B. 439.

In Dunbar v. Dunbar, 190 U. S. 340 , the court had under consideration the liability of the defendant to the plaintiff, his divorced wife, upon a contract entered into between them after a divorce, but purstiant to a pre-divorce agreement, by which contract the defendant obligated himself to pay the plaintiff a certain sum annually during her life or widowhood and also a certain sum for the support of their two children. The defendant had pleaded and proved in defense, his discharge in bankruptcy. It appeared that plaintiff had filed a claim for the amount due her at the time the petition was fled, but whether she had received a dividend is not clear. The court decided that the contract as to the plaintiff's personal claim was not provable, hence not discharged, because the contingency of her remarrying could not be accurately measured. However Mr. Justice PfckhAM, who wrote the opinion, after referring to the rule as to alimony claims as laid down in Audubon v. Shufeldt, supra, said: "We are not by any means clear that the same principle ought not to govern a contract- of this nature when, although the judgment of divorce is silent upon the subject, it is plain that the contract was made with reference to the obligations of the husband to aid in the support of the wife, notwithstanding the decree." As to the sums contracted to be paid. for the maintenance of the children the court held that the contract did not create or evidence a debt, but was merely a recognition of the father's common-law liability to support his minor children, and so that part of the claim was also held not to have been discharged.

In Victor v. Victor [1912], I K. B. 247, the Court of Appeal held that by the husband's discharge in bankruptcy, he was relieved of all liability, past, present, and future, for the payment of an annuity to his wife, the annuity having been provided for in a separation agreement entered into by the parties sometime prior to the husband's bankruptcy. The annuity in this case was to cease in case the parties resumed cohabitation. The court held, following the extremely liberal English doctrine as to the allowance of contingent claims; discussed in Hardy v. Fothergill, I3 App. Cas. 351 , that the contingency of the parties resuming cohabitation did not render the claim incapable of estimation and proof. In the L'ictor case the judges distinguish Linton v. Linton, supra, which held an alimony order unaffected by the former husband's bankruptcy discharge, on the ground that ain alimony order is subject to change at any time. It is rather odd that a court which has held that the contingency of parties resuming cohabitation, the contingency of a divorced woman remarrying, the contingency of a divorced woman not remaining chaste, (Ex parte Neal, I. R. I4 Ch. D. 579) are capable of measurement should balk when it comes to estimating the chances that a court will change an alimony order.

In 1903 \$ 17 of the Federal Bankruptcy Act was amended so as to except from the operation of a discharge in bankruptcy liabilities "for alimony due or to become due, or for maintenance or support of wife or child." This amendment became effective after the decision in the Aludubon case and after the rights of the parties in the Dunbar and $I^{\prime} r$ 'morc cases had hecome fixed. So in this country, at the present tinse, there could be no basis for a 
contention that a discharge in bankruptcy operated to relieve the bankrupt from an obligation of the sort considered in Victor v. Virlor, supra. However it does not seem necessarily settled that such a cuntract with the element of contingency eliminated may not be made the basis of a prozable claim. The Supreme Court, as alove noted, in the Dunbar case suggested that perhaps such a contract should be considered as on the same basis as an alimony order, but the decision as to the non-provability of the wife's claim was based on its contingency. A case might very easily arise where it would be very unfortunate for the wife, or former wife, if she were not permitted to prove her claim, especially as to the sums in arrears. In the alimony cases the court held that such claims were not provable eveln as to arrearages, but in the Dunbar case, in which it was a contract that was the basis of the claim, that question was not passed upon.

R. W. A. 